\title{
ARE CORPORATE SOCIAL RESPONSIBILITY ACTIVE FIRMS LESS INVOLVED IN EARNINGS MANAGEMENT? EMPIRICAL EVIDENCE FROM CHINA
}

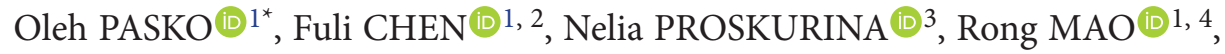 \\ Viktoriia GRYN ${ }^{3}$, Iryna PUSHKAR (D) 3 \\ ${ }^{1}$ Department of Accounting and Taxation, Sumy National Agrarian University, Sumy, Ukraine \\ ${ }^{2}$ Department of Publicity Office, Henan Institute of Science and Technology, Xinxiang, China \\ ${ }^{3}$ Department of Accounting and Taxation, Zaporizhzhya National University, Zaporizhzhya, Ukraine \\ ${ }^{4}$ Department of Business Administration, Xinxiang University, Xinxiang, China
}

Received 15 May 2021; accepted 2 November 2021

\begin{abstract}
This paper investigates whether corporate social responsibility active (CSR active) firms operate dissimilarly from other firms in their financial reporting. Specifically, we examine whether the corporate social responsibility (CSR) attitude of a firm sways its reporting incentives, in respect of the extent of earning management. To test our predictions, we use a sample of 25,861 year-company observations, corresponding to 3538 Chinese listed companies, for the period 2009-2019. We find a significant positive association between CSR activity and earning management assessed by the level of discretionary accruals in Chinese listed companies. Moreover, we document that Chinese CSR active firms engage more in earnings management through discretionary accruals than CSR inactive firms. These findings are consistent with the opportunistic financial reporting hypothesis: advances in CSR used by managers to safeguard their position by evading scrutiny from stakeholder activists. This study contributes to the growing awareness among investors, stakeholders and researchers that we should distinguish between CSR active firms and socially responsible firms and that being the latter entail something more than just mechanically produce CSR reports.
\end{abstract}

Keywords: corporate social responsibility, earnings management, discretionary accruals, opportunistic behaviour, earnings quality, China.

JEL Classification: G34, M14, M41.

\section{Introduction}

Corporate social responsibility (CSR) is on the way to becoming one of the main practices of modern companies as more and more companies under the pressure from stakeholders adopt and apply CSR disclosure practice (Adams, 2020; Gazzola et al., 2019; KPMG, 2020). Corporate social responsibility is trending upwards both in academic research (Zengul et al., 2021; Pasko et al., 2021) and in corporate practice (KPMG, 2020). The KPMG reports that the CSR reporting rate worldwide is up to 96 per cent (compared to 45 per cent in 2002) in big companies and 80 per cent (18 per cent) in the rest of the companies (KPMG, 2020, p. 10). Such a dramatic transformation of CSR into the practice of the majority begs the question of how sincere are the companies (through its senior management) in adaption of CSR practice. The extant literature developed two alternative explanation: 1) the long-term perspective hypothesis and 2) the managerial opportunism hypothesis (Choi et al., 2013; Ehsan et al., 2020; Gras-Gil et al., 2016; Zhang et al., 2021).

Some studies (Almahrog et al., 2018; Ben Amar \& Chakroun, 2018; Chen \& Hung, 2021; Gras-Gil et al., 2016; Martinez-Martinez et al., 2021; Choi et al., 2021) contend that CSR active firms are concentrated not just on raising the level of profits but also on nurturing prospective relationships with stakeholders (the long-term perspective hypothesis) (Choi et al., 2013). These companies are assumed, should behave responsible as well in reporting the accounting information. In favour of this perspective, empirical investigations reveal that committed to and active in CSR companies supply more comprehensive financial disclosures and engage less in earnings management (Bozzolan et al., 2015; Chen \& Hung, 2021;

${ }^{*}$ Corresponding author. E-mail: oleh.pasko@snau.edu.ua 
Cho \& Chun, 2016; Gras-Gil et al., 2016; Kim et al., 2012).

On the contrary, other scholars put forward the suggestion that managers might deliberately resort to CSR to conceal their opportunistic behaviours (the managerial opportunism hypothesis) (Choi et al., 2013; Kim et al., 2012). Advances in CSR could assist the managers to safeguard his or her job by evading scrutiny from stakeholder activists (Cespa \& Cestone, 2007; Muriithi et al., 2021). Moreover, a settled partnership with stakeholders can be employed as an entrenchment mechanism by managers to fight off any hostile takeovers (Arthur et al., 2019; Muriithi et al., 2021). Therefore, the managers who pursue their private rewards through distorting earnings information have incentives to be CSR active to protect their entrenchment (Choi et al., 2013). Thus, according to the managerial opportunism hypothesis CSR engagement is utilized as an efficacious strategy by a firm's managers to cover up their involvement in earning management (EM) practices (Choi et al., 2013; Ehsan et al., 2020).

In view of the fact that the empirical results are inconclusive at best, more studies are necessary to comprehend how CSR orientation can affect corporate reporting quality through lessening EM practice (Almahrog et al., 2018; Ben Amar \& Chakroun, 2018; Choi et al., 2013; Prior et al., 2008). We scrutinize whether CSR active firms conduct appropriately in financial disclosures area through constraining earnings management, thereby delivering more transparent and reliable financial information (the behaviour suits CSR active firms well) as contrasted with CSR inactive enterprises. Furthermore, although prior studies on this topic have concentrated on various institutional settings, jurisdictions and their mix, our paper bridges this gap of the existing literature through investigating the effects of CSR orientation on EM in China jurisdiction with ever-growing impact on the world economy.

Earning management is used by us following previous studies as a litmus test in determining the firms' devotion to the CSR as EM is seen as an agency cost because managers pursue their own interest to the detriment of stakeholders (Scholtens \& Kang, 2013). Given that accounting earnings figures are one of the most often cited performance statistics and that the executives have some leeway in calculating earnings without violating accounting standards principles, EM is best suited to ascertain the genuineness of manager's stance towards stakeholders and their objectives (Ehsan et al., 2020; Prior et al., 2008). Accruals are generally specified as the difference between the reported income and the cash flow (Mendes et al., 2012). However, a part of accruals is influenced by factors beyond the management control (the application of accounting standards) and called non-discretionary accruals (NDA) and a part of accruals is intentionally selected by management pursuant to its interests in terms of earnings and called discretionary accruals (DA) (Chen \& Hung, 2021; Mendes et al., 2012). Discretionary accruals are the results of management's conscious and intentional actions and as such is an excellent marker of management's adherence to CSR principles.
In our empirical analyses, we use a sample of 25,861 year-company observations of Chinese listed companies covering a period from 2009 to 2019. From a regression analysis of the data, followed by robustness tests, we find a positive association between CSR and the extent of earning management measured by discretionary accruals. Our findings indicate that active CSR firms are more likely to be involved in earnings management. We document that active in CSR have a higher level of discretional accruals compared with CSR inactive firms. Our findings lend support to the managerial opportunism hypothesis.

Our study contributes to the literature on CSR and EM in several ways. First, we provide empirical evidence based on the healthy size of the sample covering ten years that Chinese firms' managers mostly utilize CSR disclosures to conceal their opportunistic behaviour displaying bigger compared to CSR non-active firms extent of EM measured by discretionary accruals. Doing so this paper further extends the field studies on the subject matter on Asian countries that are not referred to as much as their western counterparts. Moreover, institutional theory teaches us that research results in different institutional settings may differ due to differences in reporting incentives, enforcement regimes and institutional complementarities (Wysocki, 2011), thus country-specific studies are warranted. Second, this paper provides an alert signal to policymakers and stakeholders alike that specific practices intended to enhance a firm's CSR might be just a tool for the concealment of other unscrupulous practices. Third, this study contributes to the growing awareness among stakeholders and researchers (Foster, 2021) that we ought to distinguish between active CSR firms and socially responsible firms and that being the latter entails something more than just mechanically copycat others and produce CSR reports.

The structure of the remainder of the paper is as follows. We review theories explicating the subject matter, analyse earlier research and provide the rationales for our hypothesis in section 1. Section 2 deals with the institutional background to the study, depicting CSR in China. This is followed by a "Research design" section describing the sample, variables, and empirical model to be tested. The fourth section presents the empirical results obtained. The final section of the paper illustrates the main conclusions of this study and provide a discussion of the significance of the results.

\section{Theoretical background, literature review and hypothesis development}

Theoretical background on the relationship between CSR and EM is represented by several theories, and almost each of these theories can, depending on the stance taken, explain these relationships in both negative and positive light.

Stakeholder theory. Stakeholder theory is believed to be an accepted paradigm to explain why companies engage in a socially responsible activity (Almahrog et al., 
2018; Gras-Gil et al., 2016). The main idea behind stakeholder theory that ceteris paribus, firms that practising stakeholder management will perform better in profitability, stability and growth (Gras-Gil et al., 2016, p. 290). In this regards, CSR active firms are inclined to foster longterm relationships with stakeholders rather than maximize their short-term profit and thus, "providing quality earnings is closely connected to CSR activities, especially in the aim to meet the needs of the stakeholders" (Choi et al., 2013; Gras-Gil et al., 2016). However, others authors (Almahrog et al., 2018; Sun et al., 2010) assume "a positive relationship between EM and CSR in the stakeholder theory framework" (Almahrog et al., 2018, p. 314). Managers seek to serve a multilateral set of stakeholders' objectives, while in information asymmetry which arises managers find room to practice EM. Moreover, (Almahrog et al., 2018) cite findings of (Gargouri et al., 2010; Sun et al., 2010) which testify that "companies that engage in CSR to negotiate diverse stakeholders interests are inadvertently expected to practice EM" (Almahrog et al., 2018, p. 314).

Signalling theory. The fact that CSR disclosure is reported in form of a stand-alone report as one aspect of CSR activities is evidence that firms are signalling to the market that they have some positive information to reveal. High CSR performers chose to disclose CSR related information to the public signalling their quality as signalling involves mostly quality aspect (Connelly et al., 2011). In contrast, low-quality firms in terms of CSR choose the non-disclosure route, which "consistent with constrained accounting information" (Sun et al., 2010, p. 683). Although, from a manager's standpoint, CSR activity is a signal that deflects shareholders' awareness from matters on which managers might be disciplined (García-Sánchez \& García-Meca, 2017; Gras-Gil et al., 2016; Kolsi \& Attayah, 2018).

Agency theory. Agency theory based on the assumption the information asymmetry between managers and stakeholder is high. The information asymmetry provides managers with an opportunity to practice EM. Earnings management is viewed as an agency cost because managers pursue their own interests by window-dressing financial reports that do not correspond to the real situation of the firms (Almahrog et al., 2018; Scholtens \& Kang, 2013). CSR activity implies a reduction in the level of information asymmetry and thus should raise the risk for managers to be caught red-handed in EM, therefore, agency theory implies a negative relationship between CSR and EM.

Stewardship theory. Stewardship theory as reported by (Prior et al., 2008) supports the managerial opportunism hypothesis. According to stewardship theory, a steward is expected to behave in a pro organizational manner and displaying collectivist behaviours. A genuine steward is more satisfied with serving the group as opposed to serving himself. Thus, to "benefit all stakeholders, the manager - the steward - influences reported earnings" (Prior et al., 2008, p. 173).
Stakeholder-agency theory. According to stakeholderagency theory managers are seen as unique knowledgeable stakeholders who are at the centre of the nexus of contracts. Managers are regarded as agents not shareholders, but stakeholders. To monitor management performance and lessen information asymmetry especially in the situation of "stakeholder diffusion" CSR activity in form of reporting is seen as a "monitoring structure". Thus, stakeholder-agency theory asserts that managers can undertake some EM activities seeking to acquire personal gains at the expense of other stakeholders. However, stakeholders will retort to managers provided their interests are impaired by EM practices (Sun et al., 2010). Consequently, managers are incentivized through it to exercise their control to produce more informative and extensive financial reports, seeking to lessen threats of being discharged (Almahrog et al., 2018; Sun et al., 2010).

Legitimacy theory. Legitimacy theory posits that companies are obliged by a "social contract" in which they consent to discharge various socially desired activities in exchange for the endorsement of their objectives and other benefits, and this essentially safeguards their survival (Pasko et al., 2020; Silva, 2021). Accordingly, firms issue CSR reporting seeking to legitimize their role within society, and other CSR activities are intended to bolster social behaviour by adding more credibility (Almahrog et al., 2018). Firms seek every possible undertaking to accentuate their socially acceptable behaviour and by it to enhance its legitimacy in eyes of stakeholders. However, in terms of EM (Almahrog et al., 2018; García-Sánchez \& García-Meca, 2017) imply that managers who involved in manipulative earnings realize that CSR can be exploited to preserve the firm's legitimacy, in particular in eyes of socially sensitive stakeholders (Almahrog et al., 2018; García-Sánchez \& García-Meca, 2017).

All these theories could be synthesized by two competing hypotheses about the relationship between financial transparency (proxied by EM) and CSR depending on whether the motivation is determined by a long-term perspective or by opportunistic behaviours by managers (Choi et al., 2013; Kim et al., 2012). The discourse so far engenders a rival hypothesis explicating the relation between CSR and EM.

One thread of literature, indeed prevalent one, recognize that quality earnings are strongly linked to CSR activities, in particular in that both try to meet the needs of the stakeholders (Bozzolan et al., 2015; Choi et al., 2013). It is believed that CSR active firms are less likely to manage earnings since "they do not hide unfavourable earnings realisations and, therefore, conduct no EM" (Almahrog et al., 2018, p. 313). Thus, EM is recognized as an irresponsible act that contradicts CSR principles (Almahrog et al., 2018; Choi et al., 2013). As Bozzolan et al put it "while financial transparency and accountability are vital not just to shareholders' understanding of the firm but also to all stakeholders, they are also principles that characterize a socially responsible firm" (Bozzolan et al., 2015). 
This assertion in form of a transparent financial reporting hypothesis has been proved in multiple settings from individual countries like Taiwan (Chen \& Hung, 2021), Spain (Gras-Gil et al., 2016; Martinez-Martinez et al., 2021), UK (Almahrog et al., 2018), France (Ben Amar \& Chakroun, 2018), Korea (Cho \& Chun, 2016) to international setting (Bozzolan et al., 2015; Kim et al., 2012; Scholtens \& Kang, 2013) (Table 1).
In light of the analysis provided above and taking into consideration that the majority of the extant literature came to similar conclusions (Table 1), we propose the following hypothesis:

Transparent Financial Reporting Hypothesis: A CSR active firms are less apt to engage in earnings management.

Table 1. Prior studies on the relationship between CSR and earning management

\begin{tabular}{|c|c|c|c|c|c|}
\hline Authors & $\begin{array}{l}\text { Dependable } \\
\text { variables }\end{array}$ & $\begin{array}{l}\text { Independent } \\
\text { variables }\end{array}$ & Sample & Main findings & $\begin{array}{l}\text { Lend } \\
\text { support to }\end{array}$ \\
\hline $\begin{array}{l}\text { (Chen } \\
\text { \& Hung, } \\
2021)\end{array}$ & $\begin{array}{l}\text { DA (author's } \\
\text { own formula) }\end{array}$ & CSR index & $\begin{array}{l}3,495 \text { firm-year } \\
\text { observations of } \\
\text { listed corporations in } \\
\text { nonfinancial industries } \\
\text { in Taiwan from } 2010 \text { to } \\
2014\end{array}$ & $\begin{array}{l}\text { "EM significantly less common among } \\
\text { firms with better CSR performance but } \\
\text { common among firms with poorer CSR } \\
\text { performance" (Chen \& Hung, 2021, p. 17) }\end{array}$ & TFRH \\
\hline $\begin{array}{l}\text { (Martinez- } \\
\text { Martinez } \\
\text { et al., 2021) }\end{array}$ & $\begin{array}{l}\text { Earnings } \\
\text { Management }\end{array}$ & $\begin{array}{l}\text { Corporate } \\
\text { Social } \\
\text { Responsibility }\end{array}$ & 317 Spanish SMEs & $\begin{array}{l}\text { "the stage of the industry life cycle } \\
\text { influences the EM-CSR relationship. Only } \\
\text { for SMEs with stable sales in maturity } \\
\text { sectors, lower interest in EM can be } \\
\text { significantly explained by higher CSR } \\
\text { performance" (Martinez-Martinez et al., } \\
\text { 2021, p. 399) }\end{array}$ & TFRH \\
\hline $\begin{array}{l}\text { (Gonçalves } \\
\text { et al., 2021) }\end{array}$ & $\begin{array}{l}\text { Earnings } \\
\text { management } \\
(\mathrm{DA})\end{array}$ & $\begin{array}{l}\text { Corporate } \\
\text { Social } \\
\text { Responsibility }\end{array}$ & $\begin{array}{l}568 \text { listed companies } \\
\text { from the EU, 2010-2018 }\end{array}$ & $\begin{array}{l}\text { "We find a negative relation between } \\
\text { earnings management and corporate social } \\
\text { responsibility, suggesting that managers } \\
\text { from more socially responsible companies } \\
\text { have a more ethical behavior and, thus, } \\
\text { financial reporting of higher quality" } \\
\text { (Gonçalves et al., 2021) }\end{array}$ & TFRH \\
\hline $\begin{array}{l}\text { (Almahrog } \\
\text { et al., 2018) }\end{array}$ & EM (DA) & CSR disclosure & $\begin{array}{l}\text { UK FTSE } 350 \text { index } \\
\text { during the period from } \\
2008-2010\end{array}$ & $\begin{array}{l}\text { The "results suggest that firms with } \\
\text { higher levels of CSR report lower levels of } \\
\text { discretionary accruals" (Almahrog et al., } \\
\text { 2018, p. 330) }\end{array}$ & TFRH \\
\hline $\begin{array}{l}\text { (Ben } \\
\text { Amar \& } \\
\text { Chakroun, } \\
\text { 2018) }\end{array}$ & $\begin{array}{l}\text { Earnings } \\
\text { management } \\
\text { (estimated } \\
\text { discretionary } \\
\text { accruals based } \\
\text { with CFO) } \\
\end{array}$ & CSR & $\begin{array}{l}595 \text { French firm-year } \\
\text { observations firms } \\
\text { belonging to the CAC- } \\
\text { all-Tradable index during } \\
\text { the period 2010-2014 }\end{array}$ & $\begin{array}{l}\text { "We find a negative impact of CSR on } \\
\text { earnings management. We find, also, that } \\
\text { some CSR dimensions negatively impact } \\
\text { earnings management" (Ben Amar \& } \\
\text { Chakroun, 2018, p. } 348 \text { ) }\end{array}$ & TFRH \\
\hline $\begin{array}{l}\text { (Gras-Gil } \\
\text { et al., 2016) }\end{array}$ & $\begin{array}{l}\text { Earnings } \\
\text { management }\end{array}$ & CSR & $\begin{array}{l}\text { the } 100 \text { most reputable } \\
\text { Spanish companies } \\
\text { according to the Merco } \\
\text { index for the period } \\
2005-2012\end{array}$ & $\begin{array}{l}\text { a negative impact of CSR practices on } \\
\text { earnings management }=\text { firms that are } \\
\text { more committed to CSR engage less in } \\
\text { earnings management }\end{array}$ & TFRH \\
\hline $\begin{array}{l}\text { (Cho \& } \\
\text { Chun, } \\
\text { 2016) }\end{array}$ & CSR activities & $\begin{array}{l}\text { real activities } \\
\text { earnings } \\
\text { management } \\
\text { (RAEM) }\end{array}$ & $\begin{array}{l}1432 \text { firm-year } \\
\text { observations of Korean- } \\
\text { listed firms during } \\
2005-2010\end{array}$ & $\begin{array}{l}\text { socially responsible firms are significantly } \\
\text { and negatively associated with RAEM }\end{array}$ & TFRH \\
\hline $\begin{array}{l}\text { (Muttakin } \\
\text { et al., 2015) }\end{array}$ & \begin{tabular}{|l|} 
Earnings \\
management $=$ \\
discretionary \\
accruals
\end{tabular} & $\begin{array}{l}\text { corporate social } \\
\text { responsibility } \\
\text { disclosures } \\
\text { score/index }\end{array}$ & $\begin{array}{l}135 \text { non-financial } \\
\text { companies listed on the } \\
\text { Dhaka Stock Exchange } \\
\text { (DSE) in Bangladesh } \\
\text { from } 2005 \text { to } 2009\end{array}$ & $\begin{array}{l}\text { "Our results suggest a positive relation } \\
\text { between the level of CSR disclosures } \\
\text { and earnings management measured by } \\
\text { discretionary accruals" (Muttakin et al., } \\
\text { 2015, p. 292) }\end{array}$ & OFRH \\
\hline $\begin{array}{l}\text { (Bozzolan } \\
\text { et al., 2015) }\end{array}$ & $\begin{array}{l}\text { Corporate } \\
\text { social } \\
\text { responsibility }\end{array}$ & $\begin{array}{l}\text { Earnings } \\
\text { management }\end{array}$ & $\begin{array}{l}5,863 \text { firm-year } \\
\text { observations from the } \\
\text { EIRIS database covering } \\
24 \text { different countries } \\
\text { over the period } 2003- \\
2009\end{array}$ & $\begin{array}{l}\text { "CSR is } \\
\text { negatively associated with earnings } \\
\text { management in an international setting" } \\
\text { (Bozzolan et al., 2015, p. 27) }\end{array}$ & TFRH \\
\hline
\end{tabular}


End of Table 1

\begin{tabular}{|c|c|c|c|c|c|}
\hline Authors & $\begin{array}{c}\text { Dependable } \\
\text { variables }\end{array}$ & $\begin{array}{c}\text { Independent } \\
\text { variables }\end{array}$ & Sample & Main findings & $\begin{array}{c}\text { Lend } \\
\text { support to }\end{array}$ \\
\hline $\begin{array}{l}\text { (Scholtens } \\
\text { \& Kang, } \\
\text { 2013) }\end{array}$ & $\begin{array}{l}\text { earnings } \\
\text { management } \\
\text { (earnings } \\
\text { smoothing } \\
\text { and earnings } \\
\text { aggressiveness) }\end{array}$ & CSR & $\begin{array}{l}139 \text { firms in ten Asian } \\
\text { countries included in } \\
\text { Asian Sustainability } \\
\text { Rating (ASR) report in } \\
2009 \\
\text { (Australia, China, Hong } \\
\text { Kong, India, Japan, } \\
\text { Malaysia, Pakistan, } \\
\text { Philippines, Singapore } \\
\text { and Thailand) }\end{array}$ & $\begin{array}{l}\text { "Asian firms with relatively good CSR are } \\
\text { engaged significantly less with earnings } \\
\text { management" (Scholtens \& Kang, 2013, } \\
\text { p. 95) }\end{array}$ & TFRH \\
\hline $\begin{array}{l}\text { (Kim et al., } \\
\text { 2012) }\end{array}$ & $\begin{array}{l}\text { EM } \\
\text { (the absolute } \\
\text { value of } \\
\text { discretionary } \\
\text { accruals) }\end{array}$ & $\begin{array}{l}\text { CSR score } \\
\text { according to } \\
\text { KLD ratings }\end{array}$ & $\begin{array}{l}23,391 \text { firm-year } \\
\text { observations retrieved } \\
\text { from Compustat database } \\
\text { and KLD social ratings } \\
\text { from } 1991 \text { to } 2009\end{array}$ & $\begin{array}{l}\text { "CSR firms are less likely to engage in } \\
\text { aggressive } \\
\text { earnings management through } \\
\text { discretionary accruals and/or real activities } \\
\text { manipulation" (Kim et al., 2012, p. 790) }\end{array}$ & TFRH \\
\hline $\begin{array}{l}\text { (Gargouri } \\
\text { et al., 2010) }\end{array}$ & $\begin{array}{l}\text { Earnings } \\
\text { Management } \\
\text { (Jones's (1991) } \\
\text { short-term } \\
\text { and long-term } \\
\text { models) }\end{array}$ & $\begin{array}{l}\text { Corporate } \\
\text { Social } \\
\text { Performance }\end{array}$ & $\begin{array}{l}109 \text { listed firms from } \\
\text { MJRA-CSID database } \\
\text { from } 2004 \text { to } 2005\end{array}$ & $\begin{array}{l}\text { "CSP dimensions concerning the } \\
\text { environment and employees are positively } \\
\text { associated with EM" (Gargouri et al., } \\
2010 \text {, p. } 331 \text { ) }\end{array}$ & OFRH \\
\hline $\begin{array}{l}\text { (Prior } \\
\text { et al., 2008) }\end{array}$ & $\begin{array}{l}\text { Corporate } \\
\text { Social } \\
\text { Responsibility }\end{array}$ & $\begin{array}{l}\text { Earnings } \\
\text { Management }\end{array}$ & $\begin{array}{l}593 \text { industrial firms } \\
\text { included in the } 2002- \\
2004 \mathrm{SiRi}^{\mathrm{Pro}} \mathrm{Pr}^{\mathrm{TM}} \\
\text { database }\end{array}$ & $\begin{array}{l}\text { "We find a positive impact of earnings } \\
\text { management practices on CSR; this } \\
\text { relationship holds for different robustness } \\
\text { checks" (Prior et al., 2008, p. 160) }\end{array}$ & OFRH \\
\hline
\end{tabular}

Note: TFRH - Transparent Financial Reporting Hypothesis; OFRH - Opportunistic Financial Reporting Hypothesis.

In contrast, the other thread of literature assumes opportunistic use of CSR which infers a positive relation between CSR activity and EM. The proponents of such an approach believe that earnings management practices harm the collective interests of stakeholders and that managers are well aware of it (Dechow et al., 1996; Gargouri et al., 2010; Muttakin et al., 2015). The very CSR activity shield is applied by managers to "deal with stakeholder activism and vigilance" (Prior et al., 2008, p. 160).

Some empirical studies support this hypothesis in Bangladesh (Muttakin et al., 2015) and international settings (Gargouri et al., 2010; Prior et al., 2008) (Table 1). Prior et al issue a warning that "abrupt improvements in a firm's CSR may be connected to value-destroying practices like earnings management and that these could even reinforce the negative impact of such practices on a firm's returns" (Prior et al., 2008, p. 174).

This debate results in a competing hypothesis on the relation between CSR and earnings management:

Opportunistic Financial Reporting Hypothesis: A CSR active firms are more apt to engage in earnings management.

\section{Institutional background: CSR in China}

Due to the occurrence of numerous scandals related to misconduct by Chinese companies in regards to environmental and product safety accidents, CSR in China at the beginning of the 2000s has turned to the primary point of focus for academia, government, and Chinese firms (Noronha et al., 2013; Yang et al., 2019). Oddly enough, as Lin suggests the very pervasive impression of Chinese corporate irresponsibility "may be a main driver for CSR development in China” (Lin, 2010, p. 65).

Corporate social responsibility (CSR) is discussed intensely in China since when China has been admitted into the WTO in 2001 (Yang et al., 2019), whilst the bulk of legislature related initiatives have been undertaken only since 2006 (Lee et al., 2017).

The impression of Chinese corporate irresponsibility mentioned by (Lin, 2010) has built up as a result of multiple discrediting scandals and one which stood out and gained international attention is that of the Sanlu Group milk scandal that occurred in 2008. To increase the protein content of the milk powder, the Sanlu Group added melamine to it (Yang et al., 2019). Melamine intake is known could lead to kidney stones development and in the worst case scenario could bring fatal consequences. After discovering these facts Sanlu Group went bankrupt but social consequence were much bigger and lasting. Firstly, the scandal destroyed consumers' confidence in the whole dairy industry and tarnished the perception of products labelled as "made in China". Secondly, affected kids which number is estimated to be more than 300000 could produce substantial pressure on the public medical system in the longer run (Yang et al., 2019). Furthermore, the redundant workers who were instantly left without work to feed their families compel the local and national 
government to intervene. Thus, the social cost of the scandal was enormous and the whole society has to bear it (Yang et al., 2019).

In many respects, 2008 is a watershed year witnessing not only growing public awareness due to scandals but also first actions mandating CSR reports. In January 2008 the State-Owned Assets Supervision and Administration Commission of the State Council (SASAC) issued a landmark "The Guide Opinion on the Social Responsibility Implementation by the Central-Government-Controlled State-Owned Enterprises" (Lee et al., 2017; Lin, 2010). Among the measures cited in the guidelines was that "the SOEs may issue periodic CSR reports or sustainability reports" (Lin, 2010, p. 73).

Just after that two biggest stock exchanges (Shanghai and Shenzhen) followed suit publishing their announcements which mandate CSR report for some listed companies. Shanghai Stock Exchange mandated starting from the fiscal year 2008 onward to issue CSR reports three types of listed firms: 1) firms listed in the Shanghai Stock Exchange Corporate Governance Index, 2) dual-listed companies, firms that list shares overseas, and 3) financial companies. Shenzhen Stock Exchange also from the fiscal year 2008 onward made CSR reports mandatory for firms from the Shenzhen 100 index. Besides, all listed on these exchanges companies were encouraged to publish and make public their CSR reports either (Lee et al., 2017).

Although the first real steps to establish CSR reporting landscape was taken in 2008 the foundation had already been laid before that in 2006 when the old (first adopted in 1994) The Company Law was supplemented by the definition of CSR in Article 5 "by stating that CSR is an obligation that the companies are obligated to comply with to promote social morality and business ethics under governmental supervision" (Yang et al., 2019, p. 5).

According to KPMG China's national rates of sustainability reporting, 2020 is 78 per cent (for big companies) and up 5 per cent from the 2017 level (KPMG, 2020,

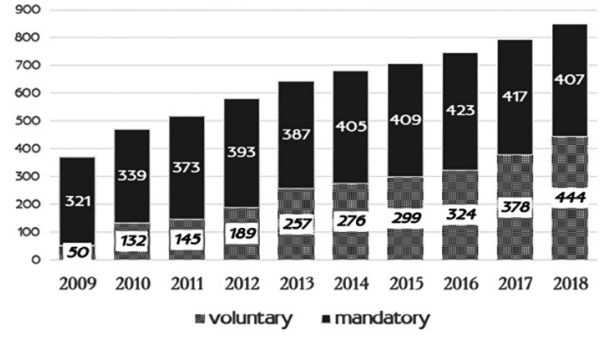

Figure 1. The number of CSR reports released by Chinese listed firms in a fiscal year (source: prepared by authors based on RKS information)

p. 15). There is an evident general tendency towards the rising number of CSR reports issued by Chinese corporations (Figure 1).

However, what is behind this increase in the number of the submitted reports just simple susceptibility to pressure from stakeholders and society as a whole and a corresponding reaction to it, or genuine changes in the philosophy of companies that lead to more appreciation of stakeholders' perspectives (a main tenet of CSR) and as a consequence more devotion to transparent financial reporting? This paper is set to reveal this on a sample of Chinese public companies.

\section{Research design}

\subsection{Data and sample selection}

Our data come from China Stock Market \& Accounting Research (CSMAR) Database. We extracted from CSMAR an initial sample of over 30.000 firm-year observations from 2009 to 2019. After screening our sample from delisted and delisting warned as well as financial companies and firms with missing data we ended up with our final sample of 25,861 year-company observations, corresponding to 3538 Chinese listed companies, covering the period from 2009 to 2019 . Table 2 shows the distribution of samples.

Table 2. Sample description: distribution of firm-year observations by industry

\begin{tabular}{|c|c|c|c|c|c|c|c|c|c|c|c|c|c|}
\hline Industry & 2009 & 2010 & 2011 & 2012 & 2013 & 2014 & 2015 & 2016 & 2017 & 2018 & 2019 & Total & $\begin{array}{l}\text { Obs } \\
(\%)\end{array}$ \\
\hline $\begin{array}{l}\text { Agriculture, } \\
\text { forestry, animal } \\
\text { husbandry and } \\
\text { fishery }\end{array}$ & 29 & 28 & 36 & 34 & 38 & 37 & 41 & 40 & 42 & 37 & 35 & 397 & 1.54 \\
\hline Mining industry & 38 & 42 & 50 & 58 & 64 & 68 & 74 & 68 & 66 & 70 & 70 & 668 & 2.58 \\
\hline Manufacturing & 860 & 881 & 1133 & 1370 & 1498 & 1507 & 1566 & 1677 & 1790 & 2106 & 2101 & 16489 & 63.76 \\
\hline $\begin{array}{l}\text { Electricity, heat, } \\
\text { gas and water } \\
\text { production and } \\
\text { supply }\end{array}$ & 61 & 67 & 70 & 76 & 80 & 82 & 88 & 94 & 100 & 103 & 100 & 921 & 3.56 \\
\hline $\begin{array}{l}\text { Construction } \\
\text { industry }\end{array}$ & 37 & 35 & 38 & 54 & 62 & 63 & 70 & 76 & 88 & 91 & 86 & 700 & 2.71 \\
\hline $\begin{array}{l}\text { Wholesale and } \\
\text { retail }\end{array}$ & 88 & 98 & 110 & 143 & 152 & 145 & 145 & 141 & 151 & 156 & 156 & 1485 & 5.74 \\
\hline
\end{tabular}




\begin{tabular}{|c|c|c|c|c|c|c|c|c|c|c|c|c|c|}
\hline Industry & 2009 & 2010 & 2011 & 2012 & 2013 & 2014 & 2015 & 2016 & 2017 & 2018 & 2019 & Total & $\begin{array}{l}\text { Obs } \\
(\%)\end{array}$ \\
\hline $\begin{array}{l}\text { Transportation, } \\
\text { storage and } \\
\text { postal industry }\end{array}$ & 63 & 66 & 74 & 77 & 81 & 81 & 80 & 84 & 87 & 91 & 94 & 878 & 3.40 \\
\hline $\begin{array}{l}\text { Accommodation } \\
\text { and Catering } \\
\text { Industry }\end{array}$ & 0 & 0 & 0 & 10 & 12 & 11 & 10 & 10 & 0 & 0 & 0 & 53 & 0.20 \\
\hline $\begin{array}{l}\text { Information } \\
\text { transmission, } \\
\text { software and } \\
\text { information } \\
\text { technology } \\
\text { service industry }\end{array}$ & 48 & 56 & 88 & 97 & 121 & 122 & 137 & 173 & 212 & 248 & 248 & 1550 & 5.99 \\
\hline Real estate & 85 & 116 & 119 & 135 & 134 & 136 & 133 & 121 & 117 & 115 & 109 & 1320 & 5.10 \\
\hline $\begin{array}{l}\text { Leasing and } \\
\text { business services }\end{array}$ & 18 & 19 & 24 & 22 & 21 & 22 & 24 & 40 & 41 & 47 & 48 & 326 & 1.26 \\
\hline $\begin{array}{l}\text { Scientific re- } \\
\text { search and tech- } \\
\text { nical service } \\
\text { industry }\end{array}$ & 0 & 0 & 0 & 0 & 12 & 11 & 17 & 21 & 27 & 46 & 48 & 182 & 0.70 \\
\hline $\begin{array}{l}\text { Water conser- } \\
\text { vancy, environ- } \\
\text { ment and } \\
\text { public facilities } \\
\text { management } \\
\text { industry }\end{array}$ & 10 & 0 & 0 & 23 & 24 & 26 & 27 & 31 & 33 & 46 & 50 & 270 & 1.04 \\
\hline $\begin{array}{l}\text { Resident servi- } \\
\text { ces, repairs and } \\
\text { other services }\end{array}$ & 0 & 0 & 0 & 0 & 0 & 0 & 0 & 0 & 0 & 0 & 12 & 12 & 0.05 \\
\hline Education & 0 & 0 & 12 & 18 & 23 & 26 & 33 & 38 & 46 & 57 & 56 & 309 & 1.19 \\
\hline $\begin{array}{l}\text { Health and } \\
\text { social work }\end{array}$ & 51 & 41 & 45 & 17 & 20 & 22 & 24 & 21 & 23 & 19 & 18 & 301 & 1.16 \\
\hline Total (Obs) & 1388 & 1449 & 1799 & 2134 & 2342 & 2359 & 2469 & 2635 & 2823 & 3232 & 3231 & 25861 & 100.00 \\
\hline CSR & 371 & 471 & 518 & 582 & 644 & 681 & 708 & 747 & 795 & 851 & 961 & 7329 & - \\
\hline $\begin{array}{l}\text { CSR active } \\
\text { companies, \% }\end{array}$ & 26.73 & 32.51 & 28.79 & 27.27 & 27.50 & 28.87 & 28.68 & 28.35 & 28.16 & 26.33 & 29.74 & 28.34 & - \\
\hline
\end{tabular}

In terms of year distribution, the observed value has steadily increased since 2009: from 1388 in 2009 to 3231 in 2019 , an increase of 232.78 per cent. From the perspective of industry distribution, the largest proportion is manufacturing (Obs $=16489$ ), accounting for 63.76 per cent, followed by IT industry (Obs $=1550)$, accounting for about 5.99 per cent, and the third is wholesale and retail $(\mathrm{Obs}=1485)$, accounting for about 5.74 per cent. The number of listed companies that issued CSR reports increased by 259.03 per cent from 2009 (371 reports) to 2019 (961 reports). However, due to the faster growth rate of the number of listed companies, the proportion of listed companies that issued CSR reports did not change much and remained at around 30 per cent.

\subsection{Measurement of variables}

Dependent variable: Earning management. The previous literature used various tools to measure earnings management, including Jones' trailblazer model which set the scene of research into this direction (Jones, 1991), a model of operating cash flows and the formal accounting process developed by (Dechow et al., 1998), the real activities manipulation model proposed by (Roychowdhury, 2006), the model of accrual quality suggested by (Dechow $\&$ Dichev, 2002) and nonlinear accruals models put forward by (Ball \& Shivakumar, 2006), etc.

Owing to its fine specification and less stringent data this study utilizes the Modified Jones Model proposed by (Dechow et al., 1996). Compatible with prior studies into this phenomenon (Almahrog et al., 2018; Ben Amar \& Chakroun, 2018; Choi et al., 2013; Gras-Gil et al., 2016; Muttakin et al., 2015), this paper makes use of the absolute discretionary accruals as a proxy for the magnitude of earnings management.

For each year and industry, we estimate the following model:

$\frac{T A_{i, t}}{A_{i, t-1}}=\alpha_{1}\left(\frac{1}{A_{i, t-1}}\right)+\alpha_{2}\left(\frac{\Delta R E V_{i, t}}{A_{i, t-1}}\right)+\alpha_{3}\left(\frac{P P E_{i, t}}{A_{i, t-1}}\right)+\varepsilon_{i, t}$, 
where: $T A_{i, t}=$ total accruals for a firm $i$ at year $t ; \Delta R E V_{t}=$ change in net revenues in year $t$ from year $t-1 ; \triangle R E C_{t}=$ change in net receivables; $P P E_{t}=$ total property, plant, and equipment in period $t ; A_{t-1}=$ lagged total assets at the end of $t-1$ year.

After running equation (1) the regression coefficient is obtained, which is then brought into the next model (2):

$$
N D A_{i, t}=\hat{\alpha}_{1}\left(\frac{1}{A_{i, t-1}}\right)+\hat{\alpha}_{2}\left(\frac{\Delta R E V_{i, t}}{A_{i, t-1}}\right)+\hat{\alpha}_{3}\left(\frac{P P E_{i, t}}{A_{i, t-1}}\right)+\varepsilon_{i, t} \text {. }
$$

Equation (2) provides us with non-discretionary accruals (NDA) and having calculated NDA we compute discretionary accruals (DA) following model (3):

$$
D A_{i, t}=\frac{T A_{i, t}}{A_{i, t-1}}-N D A_{i, t} .
$$

Independent variable: CSR. This study measures CSR engagement resorting to dummy variable: if the company issued a CSR that year, the value is 1 , otherwise, it is 0 .

Control Variables. We use several variables to control the potential effect of corporate governance and firmspecific circumstances that may impact the extent of EM. Some control variables may affect the level of earning management, so we add a set of control variables to the model. Control variables include enterprise size (LnSize), profitability (ROA), equity concentration (Top1), assetliability ratio (Leverage), and board size (BoardSize). Previous research has shown that these variables can have a significant impact on earnings management.

Empirical Model. To capture the association between earnings management and CSR engagement in financial reporting, we estimate the following model:

$$
\begin{aligned}
& D A_{i t}=\beta_{0}+\beta_{1} \text { SusRpt }_{i t}+\beta_{2} \text { LnSize }_{i t}+\beta_{3} \text { ROA }_{i t}+ \\
& \beta_{4} \text { MTB }_{i t}+\beta_{5} \text { Top }_{i t}+\beta_{6} \text { Duality }_{i t}+\beta_{7} \text { Industry }_{i t}+ \\
& \beta_{8} \text { BoardSize }_{i t}+\beta_{9} \text { Leverage }_{i t}+\text { Year }+\varepsilon_{i t},
\end{aligned}
$$

where: $R O A$ - the return on assets of the company $i$ in year $t$; MTB - the company's market-to-book ratio; Top 1 the shareholding ratio of the largest shareholder, which measures the concentration of shareholding; Industry the industry code to which the company belongs with a value of $1-9,11-19$, whilst 10 is assigned to the financial industry, not included in this research; BoardSize - the number of people on the board of directors; Leverage the ratio of liabilities to assets, and Year - the year of observation.

We summarize the definition and calculation methods of dependent, independent and control variables in Table 3.

\section{Empirical results}

\begin{tabular}{|c|c|c|}
\hline $\begin{array}{l}\text { Variable } \\
\text { Name }\end{array}$ & $\begin{array}{l}\text { Abbre- } \\
\text { viation }\end{array}$ & Definition \\
\hline \multicolumn{3}{|c|}{ Dependent variable } \\
\hline $\begin{array}{l}\text { Earning } \\
\text { Management }\end{array}$ & $\mathrm{DA}$ & Calculated from formula $1,2,3$ \\
\hline \multicolumn{3}{|c|}{ Independent variable } \\
\hline CSR Report & CSR & $\begin{array}{l}0=\text { Not issuing Corporate Social } \\
\text { Responsibility Report } \\
1=\text { Issuing Corporate Social } \\
\text { Responsibility Report }\end{array}$ \\
\hline \multicolumn{3}{|c|}{ Control variables } \\
\hline BoardSize & BoardSize & Total number of board members \\
\hline Firm Size & LnSize & Ln(Total assets) \\
\hline $\begin{array}{l}\text { Return On } \\
\text { Assets }\end{array}$ & ROA & Net profit/ Total assets \\
\hline $\begin{array}{l}\text { Return on } \\
\text { Equity }\end{array}$ & ROE & Net income / Total equities \\
\hline $\begin{array}{l}\text { Ownership } \\
\text { Concen- } \\
\text { tration }\end{array}$ & Top1 & $\begin{array}{l}\text { The shareholding ratio of the } \\
\text { largest shareholder }\end{array}$ \\
\hline $\begin{array}{l}\text { Market to } \\
\text { book ratio }\end{array}$ & MTB & Market-to-Book ratio \\
\hline Leverage & Leverage & Total liabilities / Total assets \\
\hline Industry & Industry & $\begin{array}{l}\text { The code of the company's } \\
\text { industry }\end{array}$ \\
\hline Year & Year & Current Year \\
\hline
\end{tabular}

\subsection{Descriptive statistics and univariate analysis}

Table 4 reports descriptive statistics. Table 4 shows descriptive statistics for all variables and $\mathrm{t}$-test which shows
Table 3. Variables definition

the difference between CSR active and non-active companies. Panel A of Table 4 shows a mean value of 0.012 for DA, while the average value of CSR is 0.261 , which means that only 26.1 per cent of the observations have issued sustainability reports, which is much lower compared to European and American countries. Panel B of Table 4 shows that there is a significant difference in the average DA between CSR active and CSR inactive firms significant at the level of $10 \%$. Moreover, Panel B of Table 4 testifies that CSR active firms are superior in terms of company size, profitability, the board size, and asset-liability ratio indicators. In contrast, CSR inactive firms have a higher market-to-book ratio than those of CSR active companies.

From Panel B of Table 4, we also see that the average DA of CSR active firms (0.016) is higher than that of CSR inactive firms (0.011), indicating that the former practice earning management more than the latter.

Table 5 shows the correlation matrix of the variables in the model. The highest correlation coefficients are ROA and ROE (0.884). Since ROE is a replacement variable for our robustness testing, a high correlation coefficient is auspicious for us. The explanatory variable CSR and the control variable LnSize have the highest correlation coefficient, which is 0.450 , and the correlation coefficients with other control variables are relatively low.

We also run collinearity statistics resulted in the maximum value of VIF is 2.38 and the average value is 1.34 , 
Table 4. Descriptive statistics (source: authors' calculations)

\begin{tabular}{|c|c|c|c|c|c|c|c|c|c|c|}
\hline Panel & & A & & & & & B & & & \\
\hline \multirow{2}{*}{ VarName } & \multicolumn{3}{|c|}{ Full Sample } & \multicolumn{3}{|c|}{$\mathrm{CSR}=0$} & \multicolumn{3}{|c|}{$\mathrm{CSR}=1$} & \multirow{2}{*}{ MeanDiff } \\
\hline & Obs & Mean & SD & Obs & Mean & $\mathrm{SD}$ & Obs & Mean & SD & \\
\hline $\mathrm{DA}$ & 25861 & 0.012 & 0.172 & 19118 & 0.011 & 0.183 & 6743 & 0.016 & 0.135 & $-0.004^{\star}$ \\
\hline CSR & 25861 & 0.261 & 0.439 & 19118 & 0 & 0 & 6743 & 1 & 0 & -1 \\
\hline LnSize & 25861 & 22.155 & 1.313 & 19118 & 21.804 & 1.068 & 6743 & 23.149 & 1.427 & $-1.345^{\star * *}$ \\
\hline $\mathrm{ROA}$ & 25860 & 0.039 & 0.064 & 19117 & 0.036 & 0.065 & 6743 & 0.045 & 0.06 & $-0.009^{\star * *}$ \\
\hline ROE & 25824 & 0.062 & 0.137 & 19084 & 0.055 & 0.141 & 6740 & 0.084 & 0.123 & $-0.029^{* * *}$ \\
\hline MTB & 25189 & 3.675 & 3.402 & 18566 & 3.964 & 3.622 & 6623 & 2.864 & 2.519 & $1.100^{\star * *}$ \\
\hline BoardSize & 25817 & 8.668 & 1.76 & 19082 & 8.493 & 1.641 & 6735 & 9.164 & 1.976 & $-0.671^{* * *}$ \\
\hline Leverage & 25861 & 0.441 & 0.213 & 19118 & 0.423 & 0.214 & 6743 & 0.491 & 0.199 & $-0.068^{* * *}$ \\
\hline
\end{tabular}

Note: Significance at the $10 \%, 5 \%$, and $1 \%$ levels is indicated by ${ }^{*},{ }^{* *}$, and ${ }^{* *}$, respectively.

Table 5. Bivariate correlations results (source: authors' calculations)

\begin{tabular}{|c|c|c|c|c|c|c|c|c|c|}
\hline & $\mathrm{DA}$ & CSR & LnSize & $\mathrm{ROA}$ & ROE & MTB & Industry & BoardSize & Leverage \\
\hline $\mathrm{DA}$ & 1 & & & & & & & & \\
\hline CSR & $0.011^{\star}$ & 1 & & & & & & & \\
\hline LnSize & $0.035^{\star \star \star}$ & $0.450^{\star * *}$ & 1 & & & & & & \\
\hline ROA & $0.234^{* * *}$ & $0.061^{* * *}$ & $0.023^{\star * *}$ & 1 & & & & & \\
\hline ROE & $0.224^{\star * *}$ & $0.092^{* * *}$ & $0.127^{* * *}$ & $0.884^{\star * \star}$ & 1 & & & & \\
\hline MTB & $-0.026^{* * *}$ & $-0.142^{* * *}$ & $-0.398^{\star * \star}$ & -0.003 & $-0.096^{\star * *}$ & 1 & & & \\
\hline Industry & $0.037^{\star * *}$ & $0.034^{\star \star \star *}$ & $0.076^{\star * *}$ & $0.021^{\star * *}$ & $0.024^{\star * *}$ & -0.001 & 1 & & \\
\hline BoardSize & $0.013^{\star \star}$ & $0.167^{* * *}$ & $0.276^{\star * *}$ & $0.023^{* * *}$ & $0.049^{\star * *}$ & $-0.113^{\star \star *}$ & $0.013^{\star *}$ & 1 & \\
\hline Leverage & $-0.034^{* * *}$ & $0.141^{* * *}$ & $0.464^{* * *}$ & $-0.364^{\star * *}$ & $-0.187^{\star * \star}$ & $0.014^{\star *}$ & $0.086^{* * *}$ & $0.157^{* * *}$ & 1 \\
\hline
\end{tabular}

Note: Significance at the $10 \%, 5 \%$, and $1 \%$ levels is indicated by ${ }^{\star},{ }^{\star *}$, and ${ }^{\star * \star}$, respectively.

indicating that there is no multicollinearity problem between variables.

\subsection{The relation between CSR and accrual-based earnings management}

Table 6 presents the results of multivariate regression analyses of DA and robustness testing. The result (1) is a multiple regression analysis based on formula (4), and result (2) is the robustness test there instead of ROA we employ ROE.

The multivariate regression analyses bring the findings, which are consistent with the opportunistic financial reporting hypothesis, as we find a positive association between CSR engagement and the extent of earnings management. In particular, the estimated coefficient on DA_CSR is positive and significant $(\mathrm{p}<0.10)$, denoting that CSR active firms operate earnings more through accruals. Therefore, in the Chinese institutional setting, the CSR engagement (proxy - the issuance of a CSR report) is positively associated with accrual-based earnings management.

For the control variables, both MTB $(-0.001)$ and BoardSize $(-0.002)$ are negatively correlated with earnings management and are significant at the $1 \%$ level. It is generally believed that MTB is negatively correlated with market value, that is, companies with higher market value have fewer earnings management. ROA (0.660), Leverage (0.038) and EM are positively correlated, and they are all significant at the $1 \%$ level. LnSize $(0.002)$ is positively correlated with EM, which is significant at the $10 \%$ level.

Result (2) shows the robustness test results in which we replace ROA with ROE. In the robustness test, the coefficient and pole of DA-CSR association are the same as the result (1). Only the sign of the coefficient of the control variable Leverage is different, but it is not significant. The results (3) and (4) in Table 6 are the first set of robustness tests and it could be noticed that the sign of the coefficients of each variable does not change after the addition of the variable StateOwn. Results (5) and (6) are robustness tests done to exclude endogeneity problems, using the instrumental variables (IV) techniques method, and analogous findings are obtained. Due to the limitation of the regression method (xtivreg2), we could not use Year directly in results (5) and (6), so we replicated a variable Year2 that is the same as Year. Similarly, neither (5) nor (6) output the variable _cons. The results of the robustness test show that the results of the empirical model and the robustness test model are similar and the model with its findings is reliable. 
Table 6. Regression results and robustness tests (source: authors' calculations)

\begin{tabular}{|c|c|c|c|c|c|c|}
\hline & (1) & (2) & (3) & (4) & (5) & (6) \\
\hline & $\mathrm{DA}$ & DA & DA & DA & DA & DA \\
\hline \multirow{2}{*}{ CSR } & $0.009^{*}$ & $0.010^{*}$ & $0.010^{*}$ & $0.011^{\star *}$ & $0.009^{*}$ & $0.010^{*}$ \\
\hline & $(1.74)$ & (1.95) & $(1.94)$ & $(2.17)$ & (1.74) & (1.95) \\
\hline \multirow{2}{*}{ BoardSize } & 0.001 & 0.001 & 0.001 & 0.001 & 0.001 & 0.001 \\
\hline & $(0.77)$ & $(0.80)$ & $(0.60)$ & $(0.62)$ & $(0.77)$ & $(0.80)$ \\
\hline \multirow{2}{*}{ LnSize } & $0.020^{* * *}$ & $0.025^{* * *}$ & $0.017^{* * *}$ & $0.021^{\star * *}$ & $0.020^{\star * \star}$ & $0.025^{* * *}$ \\
\hline & (6.69) & $(8.00)$ & (5.53) & (6.65) & (6.69) & (8.01) \\
\hline \multirow{2}{*}{ ROA } & $0.755^{\star * *}$ & & $0.753^{\star * *}$ & & $0.755^{\star \star *}$ & \\
\hline & (31.49) & & (31.42) & & (31.50) & \\
\hline \multirow{2}{*}{ ROE } & & $0.277^{\star * *}$ & & $0.278^{\star * *}$ & & $0.277^{* * *}$ \\
\hline & & $(27.36)$ & & $(27.38)$ & & $(27.36)$ \\
\hline \multirow{2}{*}{ Top1 } & $0.039^{\star *}$ & $0.048^{\star * *}$ & 0.019 & 0.026 & $0.039^{* *}$ & $0.048^{\star * *}$ \\
\hline & $(2.10)$ & (2.59) & $(1.01)$ & $(1.33)$ & $(2.10)$ & $(2.59)$ \\
\hline \multirow{2}{*}{ MTB } & $-0.002^{\star * *}$ & $-0.001^{\star *}$ & $-0.003^{* * *}$ & $-0.001^{* * *}$ & $-0.002^{* * *}$ & $-0.001^{* *}$ \\
\hline & $(-4.83)$ & $(-2.16)$ & $(-5.20)$ & $(-2.60)$ & $(-4.83)$ & $(-2.16)$ \\
\hline \multirow{2}{*}{ Leverage } & 0.011 & $-0.032^{* * *}$ & $0.025^{*}$ & -0.015 & 0.011 & $-0.032^{* * *}$ \\
\hline & $(0.89)$ & $(-2.59)$ & (1.94) & $(-1.21)$ & $(0.89)$ & $(-2.59)$ \\
\hline \multirow{2}{*}{ Industry } & $-0.003^{\star * *}$ & $-0.003^{* * *}$ & $-0.003^{* * *}$ & $-0.003^{* * *}$ & $-0.003^{\star * *}$ & $-0.003^{* * *}$ \\
\hline & $(-4.03)$ & $(-4.22)$ & $(-4.05)$ & $(-4.24)$ & $(-4.03)$ & $(-4.23)$ \\
\hline \multirow{2}{*}{ Year } & $-0.006^{\star * *}$ & $-0.007^{* * *}$ & $-0.006^{* * *}$ & $-0.006^{\star * *}$ & & \\
\hline & $(-11.51)$ & $(-13.01)$ & $(-9.37)$ & $(-10.53)$ & & \\
\hline \multirow{2}{*}{ Year2 } & & & & & $-0.006^{* * *}$ & $-0.007^{* * *}$ \\
\hline & & & & & $(-11.51)$ & $(-13.01)$ \\
\hline \multirow{2}{*}{ StateOwn } & & & $0.029^{* * \star}$ & $0.033^{* * *}$ & & \\
\hline & & & $(4.32)$ & $(4.92)$ & & \\
\hline \multirow{2}{*}{ _cons } & $12.540^{* * *}$ & $14.181^{* * *}$ & $10.847^{\star * *}$ & $12.218^{\star * *}$ & & \\
\hline & (11.48) & (12.98) & (9.35) & $(10.51)$ & & \\
\hline $\mathrm{N}$ & 25144 & 25144 & 25144 & 25144 & 25026 & 25026 \\
\hline $\mathrm{r} 2$ & 0.069 & 0.059 & 0.070 & 0.060 & 0.069 & 0.059 \\
\hline r2_a & -0.084 & -0.096 & -0.083 & -0.095 & -0.079 & -0.091 \\
\hline
\end{tabular}

Note: Significance at the $10 \%, 5 \%$, and $1 \%$ levels is indicated by ${ }^{*},{ }^{* *}$, and ${ }^{* * *}$, respectively.

\section{Discussions and conclusions}

This paper investigates the association between CSR activities and the extent of earnings management in China. We examined these relationships using a sample of listed Chinese firms for the period 2009-2019. We measure earnings management by the level of discretionary accruals which unlike NDA are fully under the control of managers.

We hypothesized that CSR active firms operate dissimilarly from other firms in their financial reporting and that the CSR attitude of a company sways its reporting incentives in respect of the extent of earning management. We find that CSR firms indeed behave differently from CSR non-active firms in making accounting and operating decisions. However, contrary to our expectation that CSR firms would deliver more transparent financial information to investors we conclude that they deliver less transparent financial figures. We find a significant positive association between CSR activity and earning management assessed by the level of discretionary accruals in Chinese listed companies. Moreover, we document that Chinese CSR active firms engage more in earnings management through discretionary accruals than CSR inactive firms. Our findings are on par with those of (Gargouri et al., 2010; Muttakin et al., 2015; Prior et al., 2008) and lend further support to the opportunistic financial reporting hypothesis. We add value to the literature by focusing on China the country with growing importance in the world economy. We extend previous studies on the Chinese institutional setting.

In general, our study provides intriguing implications for the debate over the benefits of CSR activity. Our findings give further credit to the suggestion that CSR active firms should not be confused with socially responsible firms (Foster, 2021). Mechanically carrying out CSR 
activity without heeding to the stakeholders' perspectives is meaningful and is a relic of the "ticking the box" mentality strongly rooted in the corporate world. We infer that earnings management is utilized by firms to impact contractual relationships based on accounting numbers and accordingly to adjust financial reporting in pursuance of misleading stakeholders regarding a firm's financial performance (Gargouri et al., 2010). This practice we stress runs counter to the fundamental premises of CSR.

Partially we could find a meaningful and logical explanation for this behaviour. The chain of events begins with a CSR activity that requires additional costs to be incurred. These costs in turn reduce the financial performance of the company, which incentivize managers to engage in EM to smooth financial performance figures. Next explanation related to the multiple objectives hypothesis put forward by (Chih et al., 2008) "which contends that multiple objectives means no objective" (Chih et al., 2008, p. 182). Multiple objectives hypothesis postulates that satisfaction of a wider group of stakeholders other than shareholders engenders a lack of performance criteria with which to assess managers and it enables managerial discretion connected with EM (Chih et al., 2008; Gargouri et al., 2010). In other words, the multiple objectives hypothesis presuppose that stakeholders might also insist on $\mathrm{EM}$, thus this practice is justified. We do not support such an approach and what we have proved is evidence that CSR active firms are not completely honest with society and with themselves. All in one our findings although run counter to reining transparent financial reporting hypothesis although are congruent with prior study's that "CSR is not a sufficient condition to get rid of earnings management" (Scholtens \& Kang, 2013, p. 108).

We infer some important policy recommendations from our analysis, which are consequential for both investors and policymakers. Investors should not preemptively infer that firms engaging in CSR activities, conduct ethically and provide transparent financial reports. As we document CSR active firms might as well and do manipulate earnings through discretionary accruals and accordingly provide less transparent financial reports to investors and shareholders. Thus, overall our advice is that the credibility and authenticity of the company's CSR policy should be appraised with caution. Likewise, CSR policies and regulations may unintentionally encourage opportunistic behaviour, rather than pushing firms and incentivizing them into social behaviour. Therefore, policymakers must exercise prudence about this opportunistic behaviour and strengthen monitoring to impose social compliance. Maybe one way out of it is a kind of regulation that would link theory and practice. This regulation would emphasize and confirm that CSR reporting is practice-based and should be assessed footed in actual practice and not only be associated with vague reports aimed at confusing stakeholders. However, the evidence collected by us may be of interest for a broad array of potential users, which are not limited solely to the academic community, investors and policymakers in particular for the financial reporting users, accounting standards-setting bodies and assurance practitioners.

The result of this study should be carefully interpreted as it has limitations that may be supplemented in future inquiries. First, this study employs dummy variable in respect to CSR, while we believe that the quality of CSR reporting could sway the results in some way and explicate deeply the matter at hand. Next, as in any empirical analysis, the results of this paper are exposed to measurement errors that might be inherent in the EM model used. A natural extension of our work is to target some distinct area of a company's CSR to detect the most relevant stakeholders to whom the company heeded when it manages its earnings. Moreover, it may be worth providing the analysis examining various sectors and institutional frameworks. Another element that we sense can open up new relationships is ownership concentration impact on EM. In conclusion, the creation of a more comprehensive analytical model of earnings management that would somehow embody ethical considerations into it is the goal that should be dealt with in the upcoming investigations.

\section{Author contributions}

OP conceived the study and was responsible for the design and overall structure of the study. CF, RM, IP and NP were responsible for data collection and analysis. CF, NP and VG were responsible for data interpretation. OP and CF wrote the first draft of the article. Authorship recognition process was guided by the Vancouver Protocol on authorship.

\section{Disclosure statement}

We know of no conflict of interest associated with this publication, and there has been no significant support for this work that could have influenced outcome.

\section{References}

Adams, C. A. (2020). Sustainability reporting and value creation. Social and Environmental Accountability Journal, 40(3), 191197. https://doi.org/10.1080/0969160X.2020.1837643

Almahrog, Y., Ali Aribi, Z., \& Arun, T. (2018). Earnings management and corporate social responsibility: UK evidence. Journal of Financial Reporting and Accounting, 16(2), 311-332. https://doi.org/10.1108/JFRA-11-2016-0092

Arthur, N., Chen, H., \& Tang, Q. (2019). Corporate ownership concentration and financial reporting quality. Journal of Financial Reporting and Accounting, 17(1), 104-132. https://doi.org/10.1108/JFRA-07-2017-0051

Ball, R., \& Shivakumar, L. (2006). The role of accruals in asymmetrically timely gain and loss recognition. Journal of Accounting Research, 44(2), 207-242. https://doi.org/10.1111/j.1475-679X.2006.00198.x

Ben Amar, A., \& Chakroun, S. (2018). Do dimensions of corporate social responsibility affect earnings management? Journal of Financial Reporting and Accounting, 16(2), 348-370. https://doi.org/10.1108/JFRA-05-2017-0033 
Bozzolan, S., Fabrizi, M., Mallin, C. A., \& Michelon, G. (2015). Corporate social responsibility and earnings quality: International evidence. The International Journal of Accounting, 50(4), 361-396. https://doi.org/10.1016/j.intacc.2015.10.003

Cespa, G., \& Cestone, G. (2007). Corporate social responsibility and managerial entrenchment. Journal of Economics \& Management Strategy, 16(3), 741-771.

https://doi.org/10.1111/j.1530-9134.2007.00156.x

Chen, R. C. Y., \& Hung, S. (2021). Exploring the impact of corporate social responsibility on real earning management and discretionary accruals. Corporate Social Responsibility and Environmental Management, 28(1), 333-351. https://doi.org/10.1002/csr.2052

Chih, H.-L., Shen, C.-H., \& Kang, F.-C. (2008). Corporate social responsibility, investor protection, and earnings management: Some international evidence. Journal of Business Ethics, 79(1-2), 179-198. https://doi.org/10.1007/s10551-007-9383-7

Cho, E., \& Chun, S. (2016). Corporate social responsibility, real activities earnings management, and corporate governance: Evidence from Korea. Asia-Pacific Journal of Accounting \& Economics, 23(4), 400-431. https://doi.org/10.1080/16081625.2015.1047005

Choi, B. B., Lee, D., \& Park, Y. (2013). Corporate social responsibility, corporate governance and earnings quality: Evidence from Korea. Corporate Governance: An International Review, 21(5), 447-467. https://doi.org/10.1111/corg.12033

Choi, J. H., Kim, S., Yang, D.-H., \& Cho, K. (2021). Can corporate social responsibility decrease the negative influence of financial distress on accounting quality? Sustainability, 13(19), 11124. https://doi.org/10.3390/su131911124

Connelly, B. L., Certo, S. T., Ireland, R. D., \& Reutzel, C. R. (2011). Signaling theory: A review and assessment. Journal of Management, 37(1), 39-67.

https://doi.org/10.1177/0149206310388419

Dechow, P. M., \& Dichev, I. D. (2002). The quality of accruals and earnings: The role of accrual estimation errors. The Accounting Review, 77(s-1), 35-59. https://doi.org/10.2308/accr.2002.77.s-1.35

Dechow, P. M., Kothari, S. P., \& L. Watts, R. (1998). The relation between earnings and cash flows. Journal of Accounting and Economics, 25(2), 133-168. https://doi.org/10.1016/S0165-4101(98)00020-2

Dechow, P. M., Sloan, R. G., \& Sweeney, A. P. (1996). Causes and consequences of earnings manipulation: An analysis of firms subject to enforcement actions by the SEC. Contemporary Accounting Research, 13(1), 1-36.

https://doi.org/10.1111/j.1911-3846.1996.tb00489.x

Ehsan, S., Nurunnabi, M., Tahir, S., \& Hashmi, M. H. (2020). Earnings management: A new paradigm of corporate social responsibility. Business and Society Review, 125(3), 349-369. https://doi.org/10.1111/basr.12198

Foster, M. J. (2021). Does CSR activity amount to socially responsible management? Philosophy of Management, 20, 391410. https://doi.org/10.1007/s40926-020-00158-6

García-Sánchez, I.-M., \& García-Meca, E. (2017). CSR engagement and earnings quality in banks. The moderating role of institutional factors. Corporate Social Responsibility and Environmental Management, 24(2), 145-158.

https://doi.org/10.1002/csr.1405

Gargouri, R. M., Shabou, R., \& Francoeur, C. (2010). The relationship between corporate social performance and earnings management. Canadian Journal of Administrative Sciences / Revue Canadienne Des Sciences de l'Administration, 27(4), 320-334. https://doi.org/10.1002/cjas.178
Gazzola, P., Amelio, S., Papagiannis, F., \& Michaelides, Z. (2019). Sustainability reporting practices and their social impact to NGO funding in Italy. Critical Perspectives on Accounting, 79, 102085. https://doi.org/10.1016/j.cpa.2019.04.006

Gonçalves, T., Gaio, C., \& Ferro, A. (2021). Corporate social responsibility and earnings management: Moderating impact of economic cycles and financial performance. Sustainability, 13(17), 9969. https://doi.org/10.3390/su13179969

Gras-Gil, E., Palacios Manzano, M., \& Hernández Fernández, J. (2016). Investigating the relationship between corporate social responsibility and earnings management: Evidence from Spain. BRQ Business Research Quarterly, 19(4), 289-299. https://doi.org/10.1016/j.brq.2016.02.002

Jones, J. J. (1991). Earnings management during import relief investigations. Journal of Accounting Research, 29(2), 193-228. https://doi.org/10.2307/2491047

Kim, Y., Park, M. S., \& Wier, B. (2012). Is earnings quality associated with corporate social responsibility? The Accounting Review, 87(3), 761-796. https://doi.org/10.2308/accr-10209

Kolsi, M. C., \& Attayah, O. F. (2018). Are socially responsible firms less engaged in earnings management? Evidence from ADX listed companies. International Journal of Business Innovation and Research, 17(4), 536-560. https://doi.org/10.1504/IJBIR.2018.096373

KPMG. (2020). The time has come. KPMG Survey of Sustainability Reporting 2020. https://assets.kpmg/content/dam/kpmg/ xx/pdf/2020/11/the-time-has-come.pdf

Lee, E., Walker, M., \& Zeng, C. (Colin). (2017). Do Chinese state subsidies affect voluntary corporate social responsibility disclosure? Journal of Accounting and Public Policy, 36(3), 179-200. https://doi.org/10.1016/j.jaccpubpol.2017.03.004

Lin, L. W. (2010). Corporate social responsibility in China: Window dressing or structural change. Berkeley Journal of International Law, 28(1), 64-100.

Martinez-Martinez, D., Andrades, J., Larrán, M., Muriel, M. J., \& Lechuga Sancho, M. P. (2021). Determinants of earnings management in Spanish SMEs and its relationship with CSR: The relevance of sector life cycle stage. Journal of Small Business and Enterprise Development, 28(3), 399-428. https://doi.org/10.1108/JSBED-07-2020-0257

Mendes, C. A., Rodrigues, L. L., \& Esteban, L. P. (2012). Evidence of earnings management using accruals as a measure of accounting discretion. Tékhne, 10(1), 3-14. https://doi.org/10.1016/S1645-9911(12)70002-6

Muriithi, S. G., Walters, B. A., McCumber, W. R., \& Robles, L. R. (2021). Managerial entrenchment and corporate social responsibility engagement: The role of economic policy uncertainty. Journal of Management and Governance. https://doi.org/10.1007/s10997-021-09569-7

Muttakin, M. B., Khan, A., \& Azim, M. I. (2015). Corporate social responsibility disclosures and earnings quality. Managerial Auditing Journal, 30(3), 277-298.

https://doi.org/10.1108/MAJ-02-2014-0997

Noronha, C., Tou, S., Cynthia, M. I., \& Guan, J. J. (2013). Corporate social responsibility reporting in China: An overview and comparison with major trends. Corporate Social Responsibility and Environmental Management, 20(1), 29-42. https://doi.org/10.1002/csr.1276

Pasko, O., Chen, F., Oriekhova, A., Brychko, A., \& Shalyhina, I. (2021). Mapping the literature on sustainability reporting: A Bibliometric analysis grounded in Scopus and Web of science core collection. European Journal of Sustainable Development, 10(1), 303-322. https://doi.org/10.14207/ejsd.2021.v10n1p303 
Pasko, O., Minta, S., Rudenko, S., \& Hordiyenko, M. (2020). Do poor and good performing companies report differently? The readability and impression management in corporate narrative documents: Evidence from Northern Europe. Business: Theory and Practice, 21(2), 835-849. https://doi.org/10.3846/btp.2020.12583

Prior, D., Surroca, J., \& Tribó, J. A. (2008). Are socially responsible managers really ethical? Exploring the relationship between earnings management and corporate social responsibility. Corporate Governance: An International Review, 16(3), 160-177. https://doi.org/10.1111/j.1467-8683.2008.00678.x

Roychowdhury, S. (2006). Earnings management through real activities manipulation. Journal of Accounting and Economics, 42(3), 335-370. https://doi.org/10.1016/j.jacceco.2006.01.002

Scholtens, B., \& Kang, F.-C. (2013). Corporate social responsibility and earnings management: Evidence from Asian Economies. Corporate Social Responsibility and Environmental Management, 20(2), 95-112.

https://doi.org/10.1002/csr.1286

Silva, S. (2021). Corporate contributions to the sustainable development goals: An empirical analysis informed by legitimacy theory. Journal of Cleaner Production, 292, 125962.

https://doi.org/10.1016/j.jclepro.2021.125962
Sun, N., Salama, A., Hussainey, K., \& Habbash, M. (2010). Corporate environmental disclosure, corporate governance and earnings management. Managerial Auditing Journal, 25(7), 679-700. https://doi.org/10.1108/02686901011061351

Wysocki, P. (2011). New institutional accounting and IFRS. Accounting and Business Research, 41(3), 309-328. https://doi.org/10.1080/00014788.2011.575298

Yang, M., Bento, P., \& Akbar, A. (2019). Does CSR influence firm performance indicators? Evidence from Chinese Pharmaceutical Enterprises. Sustainability, 11(20), 5656. https://doi.org/10.3390/su11205656

Zengul, F. D., Oner, N., Byrd, J. D., \& Savage, A. (2021). Revealing research themes and trends in 30 Top-ranking accounting journals: a text-mining approach. Abacus, 57(3), 468-501. https://doi.org/10.1111/abac.12214

Zhang, Z., Yap, T. L., \& Park, J. (2021). Does voluntary CSR disclosure and CSR performance influence earnings management? Empirical evidence from China. International Journal of Disclosure and Governance, 18, 161-178. https://doi.org/10.1057/s41310-021-00104-6 